\title{
Functional Outcome of Total Knee Replacement in Patients with Rheumatoid Arthritis - A Prospective Study
}

\author{
K R Anil Kumar Reddy ${ }^{1}$, A S Rao², AV Gurava Reddy ${ }^{1}$
}

\begin{abstract}
${ }^{1}$ Sunshine Hospital, Hyderabad, Andhra Pradesh, India.
${ }^{2}$ Krishna Institute Of Medical Sciences, Secunderabad Andhra Pradesh, India
\end{abstract}

Institute at which research was conducted: Krishna Institute of Medical Sciences, Secunderabad, India. University Affiliation of Thesis: National Board of Examination, India

Year of Acceptance: 2011

\section{Address of Correspondence}

Dr. Anil Kumar Reddy
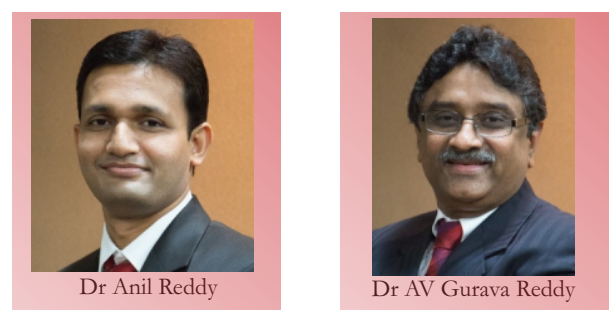

Sunshine Hospital, Hyderabad, Andhra Pradesh, India.

E mail:docanil21@gmail.com

Abstract: Background: Total knee replacement in rheumatoid arthritis requires special precautions to be taken because of valgus deformity, more blood loss, osteoporotic bone and systemic nature of disease in our study we intend to study functional outcome of total knee replacement in patients with rheumatoid arthritis.

Materials and methods: 34 patients undergoing TKR having rheumatoid arthritis as diagnosis were enrolled. knee society scores done at pre operative period and postoperatively at 3 months, 6 month and 1 year.

Results: We found out that 27 of the 34 patients had excellent functional score , 2 patients had good functional score and 2 patients had fair functional score according to Knee society scoring system at the end of 1 year.

Conclusion: More than 80 percent of patients in our study had excellent functional scores at the end of lyear. Total knee replacement is good surgical option for rheumatoid arthritis of knee.

Keywords: Rheumatoid knee, total knee replacement, functional outcome.

\section{THESIS SUMMARY}

\section{Introduction:}

The functional outcome for total knee replacement in knee arthritis has been declared excellent, most of the studies done have been for primary osteoarthritis. The available literature for total knee arthroplasties in patients with rheumatoid arthritis is very limited and almost nil specifically for Indian population. Rheumatoid arthritis is a disease which has few features inherent to it that are separate from primary degenerative osteoarthritis.characteristics commonly seen in rheumatoid arthritis are valgus deformity,juxtaarticular osteoporosis, systemic involvement of musculature,upper extremity involvement which affects rehabilitation,reduced immunity leading to wound healing problems, severe anemia which causes general malaise,younger age at presentation and ipsilateral hip involvement. We believe these characteristics may influence the surgery during total knee arthroplasty and the functional outcome of the surgery. Hence we carried out this study to assess the functional outcome of total knee replacement in patients with rheumatoid arthritis.

\section{Materials and methods:}

The subjects in the study were patients with rheumatoid arthritis who underwent total knee replacement. The diagnosis of rheumatoid arthritis was made based on criterion given by American association of rheumatologists. All the patients in the study were positive for rheumatoid factor. Our study consisted of 34 patients.28 patients were females and 6 patients were males. The age range of the patients was 40-75 and mean age was 57.6 years. Our patients were from both urban as well as rural background. Baseline scores were measured preoperatively.The patients were followed up regularly for a period of 1 year with knee society scores done at pre operative period, 3 months post operative period, 6 months post operative period and 1 year. As a routine we do cruciate retaining type of total knee arthroplasty at our hospital. However when the patients have 
valgus deformity of more than 20degrees or fixed flexion deformity of more than 40 degrees we prefer to do cruciate sacrificing type of total knee arthroplasty. In our study of 34 patients we had 5 patients who underwent cruciate sacrifing type of total knee arthroplasty either because of severe deformity, ligamentous instability or difficulty in soft tisse balancing.

\section{Results:}

Patients with total knee replacement has excellent outcome in patients with rheumatoid arthritis. More than 80 percent of patiens in our study had excellent functional scores at the end of 1year.Age of the patient at the time of presentation doesn't have direct linear correlation to functional outcome. The patients in the younger age group had better functional scores than the older age group, however the mean improvement in functional scores was similar in all age groups. Weight of patient also did not show direct linear correlation to functional outcome. Patients in different weight groups showed similar mean improvement in functional scores. However, the morbidly obese patients took longer time to achieve better functional scores when compared to the others. The associated comorbid conditions such as Diabetes mellitus .Hypertension and Coronary artery disease did not influence the functional outcome of the surgery per se. The data in our study group showed significant difference in functional outcome after total knee arthroplasties between the 2 groups. The group where PCL was retained had superior clinical and functional scores compared to the group where PCL was sacrificed. However the difference was more significant in functional scores than clinical scores. Patelloplasty was done in all the patients who underwent toal knee arthroplasty in our study.

\section{Conclusion:}

In our study we observed and analysed the data of 34 patients with rheumatoid arthritis who underwent total knee arthroplasty without patellar resurfacing. All the patients were evaluated according to knee society scoring system. 3 patients were lost for follow Up in our study at the end of 1 year. we found out that 27 of the 34 patients had excellent functional score, 2 patients had good functional score and 2 patients had fair functional score according to Knee society scoring system at the end of 1 year.Total knee arthroplasty in patients with rheumatoid arthritis is a "good surgical option" with about 80 percent of people having "excellent" functional outcome according knee society scoring system.

Key Words:

Rheumatoid knee, total knee replacement, functional outcome.

\section{Bibliography}

1.Kristensen-O. Nafei-A. Kjaersgaard-Andersen-P. Hvid-I. Jensen-J. Long-term results of total condylar knee arthroplasty in rheumatoid arthritis. J-Bone-Joint-Surg-Br. 1992 Nov. 74(6). P 803-6.

\section{Laskin.RS : Total condylar knee replacement in patients who} have rheumatoid arthritis: a ten year follow up study. J Bone
Joint Surgery 1990; 72:529-535.

3.Amenábar PP, Carrión M, Apablaza D, Paulos J. Total knee arthroplasty in patients with rheumatoid arthritis.

4.Krackow KA, Jones MM, Teeny SM, Hungerford DS. Primary total knee arthroplasty in patients with fixed valgus deformity.Clin Orthop Relat Res. 1991 Dec;(273):9-18.

5.Sasanuma H, Sekiya H, Takatoku K, Takada H, Sugimoto N.Evaluation of soft-tissue balance during total knee arthroplasty. J Orthop Surg (Hong Kong).2010 Apr;18(1):2630 .

6.Laskin. RS, O'Flynn HM: Total knee replacement with posterior cruciate ligament retention in rheumatoid arthritis: problems and complications. Clin Orthop 1997;345:24-28.

7.Schai PA, Scott RD, Thornhill TS: Total knee arthroplasty with Posterior cruciate retention in patients with rheumatoid arthritis Clin Orthop 1999;367:96-106.

8.Steinberg J, Sledge CB, Noble J, Stirrat CR: A tissue-culture Model for cartilage breakdown in rheumatoid arthritis: quantitative aspects of proteoglycan release.Biochem $J$ 1979;180:403-412.

9.Sun Z, Sun Y, Cao J, Wang L, Tian M, Zhang Y, Liu J, Wang P. Cause analysis and clinical management of postoperative wound complications after total knee arthroplasty Chinese journal of reparative and reconstructive surgery 2009 Jun;23(6):644-7.

10.Patella V, Speciale D, Patella S, Moretti B, Pesce V, Spinarelli A. Wound necrosis after total knee arthroplasty. Orthopedics. 2008 Aug;31(8):807.

11.Yurube T, Takahi K, Owaki H, Fuji T, Kurosaka M, Doita M. Late infection of total knee arthroplasty inflamed by antiTNFalpha, Infliximab therapy in rheumatoid arthritis.Rheumatol Int. 2010 Jan;30(3):405-8.

12.Debarge R, Nicolle MC, Pinaroli A, Ait Si Selmi T, Neyret P. Surgical site infection after total knee arthroplasty: a monocenter analysis of 923 first-intention implantations. Rev Chir Orthop Reparatrice Appar Mot. 2007 Oct;93(6):582-7.

13.Simmons TD, Stern SH.Department of Orthopaedic Surgery, Diagnosis and management of the infected total knee arthroplasty. Am J Knee Surg. 1996 Spring;9(2):99-106.

14.Laiho K, Mäenpää H, Kautiainen H, Kauppi M, Kaarela $K$, Lehto $M$, Belt E. Rise in serum $C$ reactive protein after hip and knee arthroplasties in patients with rheumatoid arthritis. Ann 
Rheum Dis. 2001 Mar;60(3):275-7.

15.Gualtieri G, Bettelli G, Ferruzzi A, Calderoni P, Gualtieri I,Knee prosthesis in rheumatoid patients. Chir Organi Mov. 1997Jul-Sep;82(3):269-74.

16. Holt $G$, Miller $N$, Kelly MP, Leach WJ. Retention of the patella in total knee arthroplasty for rheumatoid arthritis.Joint Bone Spine. 2006 Oct;73(5):523-6. Epub 2006 Apr 19.

17.Ogon M, Hartig F, Bach C, Nogler M, Steingruber I,Biedermann R. Patella resurfacing: no benefit for the long-term outcome of total knee arthroplasty. A 10- to 16.3-year follow-up. Arch Orthop Trauma Surg. 2002 May;122(4):229-34. Epub 2002 Jan 8 .

18.Hasegawa M, Ohashi T. Long-term clinical results and radiographic changes in the nonresurfaced patella after total knee arthroplasty: 78 knees followed for mean 12 years. Acta Orthop Scand. 2002 Oct;73(5):539-45.

19. Bhan S, Malhotra R, Eachempati KK. Total knee arthroplasty without patellar resurfacing in patients with rheumatoid arthritis. Clin Orthop Relat Res. 2006 Sep;450:157-63.

20.Goldring SR, Wojno WC,Schiller AL,Scott RD: In patients with rheumatoid arthritis the tissue reaction associated with loosened total knee replacements exhibits features of a rheumatoid synovium.JOrtho Rheum 1988;1:9-21.

21.Steinberg J, Sledge CB, Noble J,Stirrat CR: A tissue-culture Model for cartilage breakdown in rheumatoid arthritis: quantitative aspects of proteoglycan release.Biochem J 1979; 180:403-412.

22.Aaron RK,Scott RD: Supracondylar fracture of femur after total knee arthroplsty. Clin Orthop 1987;291:136-139.

23.Garcia RM, Hardy BT, Kraay MJ, Goldberg VM. Revision total knee arthroplasty for aseptic and septic causes in patients with rheumatoid arthritis. Clin Orthop Relat Res.
2010 Jan;468(1):82-9.

24.Naal FD, Wasmaier J, Guggi T, Munzinger U. Reconstruction of severe uncontained bone defects in revision total knee arthroplasty in a patient with rheumatoid arthritis. Acta Orthop Belg. 2008 Apr;74(2):255-60.

25.Laskin. RS,O'Flynn HM: Total knee replacement with posterior cruciate ligament retention in rheumatoid arthritis: problems and complications. Clin Orthop 1997;345:24-28.

26.Bu Y, Yu J, Zhao X, Zheng D, Zhang T. Clinical research of posterior cruciate ligament-retained mobile-bearing total knee arthroplasty in treatment of rheumatoid arthritis Zhongguo Xiu Fu ChongJian Wai Ke Za Zhi. 2010 Jun;24(6):696-700.

27.LaskinRS Total condylar knee replacement in patients who have rheumatoid arthritis. A ten-year follow-up study.J Bone Joint Surg Am. 1990 Apr; 72(4):529-35.

28.Bourne RB, Rorabeck CH, Yaz M, Kramer J. Resurfacing versus non resurfacing the patella during total knee replacement. Clin Orthop Relat Res. 1995;321 : 156-161.

29.Levistsky KA, Harris WJ, Mcmanus J, Scott RD. Total knee arthroplasty without patellar resurfacing : clinical outcomes and long term follow-up evaluation.Clin Orthop Relat Res.1993;286:116-121.

30. Vince KG, Mcpherson EJ. The patella in total knee arthroplasty. Orthop Clin North Am. 1992;23: 675-686.

31.Sledge CB, Edwald FC. Total knee arthroplasty experience at the Robert Breck Brigham Hospital. Clin Orthop Relat Res.1979; 145:78-84.

32.Keblish PA, Varma AK, Greenwald AS. Patellar resurfacing or retention in total knee arthroplasty : a prospective study of patients with bilateral replacements. J Bone Joint Surg Br.1994; $76: 930-937$
Conflict of Interest: Nil

Source of Support: None
Full Thesis and Master Chart available on www.journalmedicalthesis.com

How to Cite this Article:

Reddy AK, Rao AS, Reddy AVG. Functional Outcome of Total Knee Replacement in Patients with Rheumatoid Arthritis - A Prospective Study. Journal Medical Thesis 2013 July-Sep; 1(1):20-22 